Volume 6

Issue 2 Volume VI, Part Two, Spring 1989

Article 10

1989

\title{
The United Nations and the Maintenance of International Peace and Security
}

Ved P. Nanda

Follow this and additional works at: https://digitalcommons.nyls.edu/journal_of_human_rights

Part of the Law Commons

\section{Recommended Citation}

Nanda, Ved P. (1989) "The United Nations and the Maintenance of International Peace and Security," NYLS Journal of Human Rights: Vol. 6 : Iss. 2 , Article 10.

Available at: https://digitalcommons.nyls.edu/journal_of_human_rights/vol6/iss2/10

This Book Review is brought to you for free and open access by DigitalCommons@NYLS. It has been accepted for inclusion in NYLS Journal of Human Rights by an authorized editor of DigitalCommons@NYLS. 
The United Nations And The Maintenance Of International PEACE AND SECURITY. United Nations Institute for Training and Research. Dordrecht/Boston/Lancaster: Martinus Nijhoff Publishers, 1987, Pp. xviii, 421. Index. $\$ 64.00$

\section{Reviewed by Ved P. Nanda}

The publication of this collection of fourteen papers in The United Nations and the Maintenance of International Peace and Security ${ }^{1}$ preceded the recent success of the United Nations in both peacemaking and peacekeeping. ${ }^{2}$ Prepared as working papers for a meeting jointly organized by the United Nations Institute for Training and Research (UNITAR) and Columbia University in September 1986 in connection with the celebration of 1986 as the International Year of Peace, this collection provides a retrospective as well as prospective view of the United Nations' role in the area of peace and security.

Twelve of the fourteen papers in the book are original contributions. ${ }^{3} \quad$ The authors include academicians, government officials, diplomats, and international civil servants, bringing varying perspectives to the subject with their contributions ranging from short policy essays to thoroughly researched papers. Unlike many collections, however, the quality remains consistently superior.

Professor Ernst Haas ${ }^{4}$ provides a detailed and comprehensive historical context in his opening essay addressing the United Nations record in managing international conflicts during the period 1945-

\footnotetext{
* Thomas G. Marsh Professor of Law at the University of Denver Law School; Director, International Legal Studies Program.

1. UnitaR, The Unirted Nations And The Maintenance Of International Peace And SECURITY (1987).

2. See, e.g., A U.N. Success - - Four-Part Afghanistan Agreement Signed in Geneva, 25 U.N. CHron. No. 2, June 1988, at 4; 1988 Nobel Peace Prize Awarded to U.N. Peacekeeping Forces, 25 U.N. Chron., No. 4, Dec. 1988, at 4-25.

3. Two of the papers in this collection were originally prepared for other purposes and later contributed to this collection. See Haas, The Collective Management of International Conflich, 1945-1984, in UNITAR, supra note 1, at 3; Urquhart, United Nations Peacekeeping Operations and How Their Role Might Be Enhanced, in UNITAR, supra note 1, at 253. These papers originally appeared as a UNITAR Study and a paper for the Palme Commission's Meeting in New Delhi India in January 1986, respectively.

4. UNITAR, supra note 1, at xiv-xv. Ernest B. Haas is an author and Robson Research Professor of Government at the University of California, Berkeley. He served as a member of the Committee of International Organizations of the Social Science Research Counsel and as a member of the editorial committee of the journal, Intemational Onganization. Id.
} 
1984. ${ }^{5}$ Subsequent papers are clustered under the following four headings which constitute parts two through five of this collection respectively: (1) The United Nations and the Peaceful Settlement of Disputes; ${ }^{6}(2)$ United Nations Peacekeeping Operations,; (3) The United Nations and Disarmament; ${ }^{8}$ and (4) Novel Threats to International Peace and Security, which consists of a short paper on international terrorism by the RAND Corporation's Brian Jenkins.'

The United Nations' Secretary-General, Javier Perez de Cuellar, sets the tone by challenging the academic community and nongovernment organizations (NGO's) to undertake "work of analysis and clarification," ${ }^{10}$ with the objective of scrutinizing "the often ill-based assumptions, fears and suspicions and outdated notions of national interest that influence official [state] policies in a direction contrary to what is envisaged in the [U.N.] Charter."11 $\mathrm{He}$ observes that such clarification would make it easier for governments to take into account the larger international interest and to "view situations in a long-term perspective."12

In the opening essay in this collection, Haas concludes that in the sphere of conflict management it will take time before "relation-

5. Haas, The Collective Management of Intemational Conflict, 1945-1984, in UNITAR, supra note 1 , at 3.

6. Part two of this collection consists of five essays. See Broms, The Role of the United Nations in the Peaceful Settlement of Disputes, in UNITAR, supra note 1, at 73; Eide, Outlawing the Use of Force: The Effors by The United Nations, in UNITAR, stpra note 1, at 99; Lachs, United Nations and the Imtemational Court of Justice, in UNITAR, supra note 1, at 147; Cordovez, Strengthening United Nations Diplomacy for Peace: The Role of the Secretary. General, in UNITAR, supra note 1, at 161; Elaraby, The Office of the Secretary-General and the Maintenance of Intemational Peace and Security, in UNITAR, stpra note 1, at 177.

7. Part three of this collection consists of four essays. See James, The Enforcement Provisions of the United Nations Charter, in UNITAR, supra note 1, at 213; Malitza, The Improvements of Effectiveness of United Nations Peacekeeping Operations, in UNITAR, supra note 1, at 237; Urquhart, United Nations Peacekeeping Operations and How Their Role Might Be Enhanced, in UNITAR, supra note 1, at 253; Wiseman, The United Nations and International Peacekeeping: A Comparative Analysis, in UNITAR, supra note 1, at 263.

8. Part four of this collection consists of three essays. See Bougrov, Conceptual and Practical Aspects of United Nations' Activities in the Field of Disarmament, in UNITAR, supra note 1, at 337; Goldblat, The Role of the United Nations in Ams Control: An Assessment in UNITAR, supra note 1, at 369; Poulose, The United Nations and Arms Control: Nuclear Proliferation, in UNITAR, supra note 1 , at 387.

9. Jenkins, International Terrorism: A New Challenge for the United Nations, in UNITAR, supra note 1, at 407.

10. Perez de Cuellar, Foreword to UNITAR, supra note 1, at xii.

11. Id

12. Id. 
ships of constraints" develop among nation states to trigger the process of reciprocity at the United Nations. ${ }^{13}$ Rejoicing that "enough has been learnt to permit the control of some very nasty threats to the peace, ${ }^{114}$ he suggests that "[t]he evolution of human consciousness does not depend upon the geologic time scales of biological evolution; but it takes more than forty years." ${ }^{\text {"15 }}$

A total of five papers address the role of the United Nations in the peaceful settlement of disputes: three on promoting the rule of law ${ }^{16}$ and two on the role of the Secretary-General. ${ }^{17}$ Bengt Broms, ${ }^{18}$ Professor of International Law at the University of Helsinki, describes the various attempts by the United Nations to develop the existing means and methods to promote the peaceful settlement of disputes. ${ }^{19}$ More recently, in March 1988, he chaired a special committee of the General Assembly which drafted a declaration on the prevention and and removal of disputes and situations likely to threaten international peace and security, recommending specific measures for the Security Council and the Secretary-General. ${ }^{20}$

In his chapter on the efforts of the United Nations in outlawing the use of force, ${ }^{21}$ Asbjorn Eide, ${ }^{2}$ Director of the Norwegian Institute of Human Rights, concludes the United Nations

13. Haas, supra note 5 , at 57-58.

14. Id. at 58.

15. Id

16. Broms, supra note 6, at 73; Eide, supra note 6, at 99; Lachs, stpra note 6, at 147.

17. Cordovez, supra note 6, at 161; Elaraby, supra note 6, at 177.

18. UNITAR, supra note 1 , at xiii. Professor Broms is an author and a member of the Finnish High Court of State, and the Finnish Academy of Sciences.

19. Broms, supra note 6, at 73. Professor Broms includes a discussion on the U.N. Charter, General Assembly Resolutions, recent proposals by the General Assembly and the International Court of Justice, as methods of promoting the peaceful settlement of disputes. See, e.g., Declaration on Principles of Intermational Law Concerning Friendly Relations and Cooperation Among States in Accordance with the Character of the United Nations, G.A. Res. 2625 (XXV), 25 U.N. GAOR Supp. (No. 28) at 121, U.N. Doc. A8028 (1970); Declaration on the Use of Scientific and Technological Progress in the Interests of Peace and for the Benefit of Mankind, G.A. Res. 3384 (XXX), 30 U.N. GAOR Supp. (No. 34) at 86, U.N. Doc. A/10034 (1975).

20. Charter Committee Approves Drafi Declaration on Prevention of Threats to Peace, 25 U.N. CHRON., No. 2, June 1988, at 63.

21. Eide, supra note 6, at 99 .

22. UNITAR, supra note 1, at xiii. Mr. Eide was formerly the Secretary-General of the International Peace Research Association, taught International Law at the University of Oslo, and was a Fellow of the School of International Affairs of Columbia University. 
"will be unable to move significantly towards the prohibition of the use of force"23 until the organization addresses "the problems underlying the arms race itself."24 A judge of the International Court of Justice and a noted authority on international law, Manfred Lachs, ${ }^{25}$ makes a plea for member states of the United Nations "to seek more frequent recourse to the Court in contentious cases, as well as to review legal questions . . f for advisory opinions." ${ }^{.26}$ It is worth noting that on November 18, 1987, the United Nations General Assembly adopted a declaration on the non-use of force in international relations. ${ }^{27}$

On the role of the Secretary-General, Diego Cordovez, the United Nations Under-Secretary General for Special Political Affairs, ${ }^{28}$ and Nabil Elaraby, Egypt's representative to the United Nations in Geneva, ${ }^{29}$ provide useful insights. ${ }^{30}$ Both authors seek an expanded role for the office of the Secretary-General and offer various suggestions to achieve such a role: to have direct access to the International Court of Justice to request advisory opinions, ${ }^{31}$ to initiate fact-finding missions, ${ }^{32}$ and to intervene "before the flare-up of a given crisis. ${ }^{133}$

The four chapters addressing the United Nations peacekeeping operations provide a most useful analysis of the strengths and weaknesses of this success story of the United Nations. The thrust is that peacemaking and peacekeeping must be closely linked. ${ }^{34} \mathrm{~A}$ leading authority in the field of peacekeeping and a Professor of Political Science at the University of Guelph in Canada, Henry

23. Id at 144 .

24. Id

25. UNITAR, supra note 1 , at $x v$.

26. Lachs, supra note 6 , at 147,158 .

27. See The Declaration on the Enhancement of the Effectiveness of the Principle of Refraining from the Threat or Use of Force in International Relations, G.A. Res. 42/22, 42 U.N. GAOR Supp. (No. 49) at 287, U.N. Doc. A/42/49 (1987).

28. UNITAR, supra note 1 , at xiii.

29. Id at xiv.

30. See Cordovez, supra note 6, at 161; Elaraby, supra note 6, at 177.

31. Cordovez, supra note 6 , at 171.

32. Id

33. Elaraby, supra note 6 , at 201.

34. See James supra note 7, at 231-32; Maliyza, supra note 7, at 245-51; Urquhart, supra note 7, at 258-60; Wiseman, supra note 7, at 329 . 
Wiseman, ${ }^{35}$ presents a fairly exhaustive comparative analysis of the United Nations and international peacekeeping. ${ }^{36} \mathrm{He}$ divides the United Nations operations into four periods: (1) the nascent period, $1946-1956 ;{ }^{37} 12$ (2) the assertive period, $1956-1967 ; ;^{38}(3)$ the dormant period, $1967-1973 ;^{39}$ and (4) the resurgent period 1973-1978. ${ }^{40} \mathrm{He}$ finds that since 1978 the United Nations "has effectively restrained from utilizing its peacekeeping competence except in the Middle East. ${ }^{141} \mathrm{He}$ also studies regional efforts by the Organization of American States and the Organization of African Unity on independent ad hoc peacekeeping in response to particular crises,

35. UNITAR, supra note 1 , at xvi. Professor Wiseman is a leading authority in the field of peacekeeping. Formerly a visiting Scholar at UNITAR, Professor Wiseman has been awarded the Canadian Silver Jubilee Medal for his work in the field of international peacekeeping.

36. Id

37. Id at 266-37. The author describes this period as the development stage in the process of United Nations management of conflict. During this period the United Nations engaged in the following four "observer-type" missions, which the author discusses in detail: The United Nations Special Committee on the Balkans (UNSCOB); the establishment of special commissions to supervise the cease-fire that led to the independance in Indonesia; the Truce Commission for the Middle East; and The United Nations Military Observer Group in India and Pakistan (UNMOGIP). Id

38. Id at 273-88. The assertive period is described as a period of "bold and assertive peacekeeping action" by the United Nations. This period saw the development of four "observer-type" missions: U.N. Observations Group in Lebanon (UNOGIL); U.N. Yemen Observation Mission (UNYOM); Mission of the Representatives of the Secretary-General in the Dominican Republic (DOMREP); and U.N. India-Pakistan Observation Mission (UNIPOM). During this period three large scale peacekeeping operations also developed: U.N. Emergency Force (UNEF); U.N. Operations in the Congo (ONUC); and U.N. Peacekeeping Force in Cyprus (UNFICYP).

39. Id. at 288-91. The dormant period describes a six-year period when there were no peacekeeping nor "observer-type" operations established. While there were several conflicts during this period that could have resulted in a U.N. peacekeeping response, this did not occur. The author suggests three reasons why no such action was taken: (1) history demonstrated that the United Nations only acted when a crisis reached a critical or threatening stage; (2) the creation of the Organization of African Unity; and (3) the continuing controversy between the United States and the Soviet Union "over issues of the residual authority of the General Assembly, the mode of financing and the level of authority of the Secretary-General in the conduct of peacekeeping operations." Id.

40. Id. at 291. Several crises during this period brought out the United Nations peacekeeping operations. The author explains that joint Egyptian-Syrian attacks on Israel resulted in the establishment of the United Nations Emergency Force II (UNEF II) and the United Nations Disengagement Force (UNDOF). A third peacekeeping operation, United Nations Interim Force in Lebanon (UNIFIL), developed as the result of the Israeli attack on Lebanon. The effectiveness of the United Nations peacekeeping operations greatly expanded during this period.

41. Wiseman, supra note 7 , at 291. 
such as the multinational force in Beirut. ${ }^{42}$ Decrying the increased use of independent ad hoc arrangements, he calls upon the U.N. members "to resist the trend and make the United Nations what it was intended to be."43

Brian Urquhart, formerly the Under-Secretary-General of the United Nations until his retirement in February 1986, ${ }^{44}$ argues that real progress in U.N. peacekeeping, a "valuable and promising technique, ${ }^{45}$ is possible only if attention is paid "to the wider context in which peacekeeping operates, or could operate, and to the essential factors of political climate, environment and international leadership." ${ }^{146}$ Among other recommendations, he calls for a permanent international peacekeeping establishment ${ }^{47}$ the strengthening of international peacemaking and peacekeeping by the work of the Security Counsel, the Secretary-General, and regional organizations, ${ }^{48}$ and concludes that peacekeeping could be more useful and effective "if these objectives were championed by determined international leadership which also provides more consistent and unequivocal support for international peacekeeping efforts. ${ }^{\text {"49 }}$ In their contributions, Mircea Malitza, a Professor of Applied Mathematics at the University of Bucharest, Romania, ${ }^{50}$ and Alan James, currently the head of the department of International Relations at University of Keele in the United Kingdom, ${ }^{51}$ also offer specific suggestions for enhancing the effectiveness of U.N. peacekeeping operations. ${ }^{52}$

42. Id. at 309-15.

43. Id at 330 .

44. UNITAR, supra note 1, at xvi. Professor Urquhart is currently a Scholar-in-Residence at the Ford Foundation.

45. Urquhart, supra note 7 , at 253.

46. Id.

47. Id. at 260.

48. Id. at 258-59.

49. Id. at 260 .

50. UNITAR, supra note 1 , at xv-xvi. Mr. Malitza was Counsellor to the Permanent Mission of Romania to the United Nations, 1956-1961, Deputy Minister of Foreign Affairs, 1962-1970, Minister of Education, 1970-1972, Ambassador to Switzerland, 1980-1982, and Ambassador to the United States, 1982-1985.

51. Id. at xv. Professor James is an author and former Chairman of the British International Studies Association.

52. See Malitza, supra note 7, at 248. The author suggests the establishment of a Commission for Good Offices, Mediation and Conciliation to clarify aspects of the dispute and differences of perception, delineate facts, and elaborate suggestions for the initiation of 
The three chapters on the United Nations and disarmament are authored by Evgheny V. Bougrov, who is associated with the Institute of the World Economy and International Relations of the USSR Academy of Sciences, ${ }^{53}$ Joseph Goldblat of the Stockholm International Peace Research Institute (SIPRI), ${ }^{54}$ and T. T. Poulose, a Professor of Disarmament at Jawaharlal Nehru University in New Delhi. ${ }^{55}$ The lack of progress at the United Nations on arms control and disarmament is the running theme of these chapters. Bougrov calls for the United Nations "to encourage world public opinion to put more pressure on the countries that refuse to abandon the path of militarism."156 Similarly, Goldblat concludes that "[i]n the final analysis, however, it is the growing public concern about the dangers of the arms race that may be decisive. ${ }^{157}$ Poulose addresses the nuclear proliferation issue and makes specific recommendations for revising the Nuclear Nonproliferation Treaty. ${ }^{58}$

It is appropriate to remind ourselves that the third United Nations Special Assembly on Disarmament, which met in New York in June 1988, failed to reach consensus on a concluding document establishing new aims and priorities in the field of disarmament. ${ }^{59}$

In a short essay, comprising the last chapter of this collection,

negotiotions. Id ; James, supra note 7, at 233. The author suggests the inclusion of one or more of the superpowers may increase organizational efficiency and operational effectiveness of a U.S. peacekeeping force, as well as "show the world their active concern that peace should be maintained in a particular area." Id.

53. UNITAR, supra note 1 , at xiii. Mr. Bougrov, an expert in world economy, heads the department of military-economic and military-political research at the Institute of the World Economy and International Relations of the USSR Academy of Sciences. Id.

54. Id at xiv. Mr. Goldblat is a senior member of the Research Staff of the Stockholm International Peace Research Institute (SIPRI). He has studied arms control and has actively participated in international commissions on this topic.

55. Id. at xvi. Professor Poulose has authored several books on arms control in the third world. See, e.g., Poulose, Nuclear Proliferation ANd THe Third World (1986); Poulose, The Future Of Nuclear Arms Control (1987).

56. Bougrov, supra note 8 , at 365 .

57. Goldblat, stupra note 8 , at 385 .

58. Poulose, supra note 8 , at 402 . Professor Poulose suggests the Nuclear Non-Proliferation Treaty be revised to (1) comply with the requirements of United Nations Resolution 2028 $(\mathrm{XX}) ;(2)$ amend Article III to make the Non-Proliferation Treaty safeguards applicable to nuclear weapon states and non-nuclear-weapon states alike, (3) to insert a new provision to cover vertical proliferation, and (4) add a new provision incorporating nuclear security guarantees to those nations becoming parties to the treaty. Id.

59. Third Special Assembly on Disarmament -- High-Level Debate, Innovative Proposals Highlight Session -- No Consensus on Concluding Documents, 25 U.N. CHRON., No. 3, Sept. 1988, at 4-23. 
Brian Jenkins ${ }^{60}$ suggests that the United Nations' ongoing piecemeal approach to international terrorism, instead of seeking a comprehensive solution which is impractical because of a lack of consensus on the definition of terrorism, offers the only practical way to address this urgent challenge. ${ }^{61}$

Now that the United Nations has succeeded in its efforts to negotiate a withdrawal of the Soviet forces from Afganistan, to halt the Iran-Iraq war, to find a solution to the Cyprus problem and to the protracted conflicts in Namibia and Kampuchea, the subject of the book assumes greater significance as well as a sense of urgency. Among the recent salutory developments are the awarding of the 1988 Nobel Peace Prize to U.N. Peacekeeping Forces, ${ }^{62}$ the new initiatives by the Soviet Union on the enhanced use of the United Nations peacemaking and peacekeeping, ${ }^{63}$ and the continuing confidence expressed by the permanent members of the Security Council in the United Nations' role in the achievement of international peace and security. ${ }^{64}$

In this special atmosphere when the United Nations is enjoying a new respectibility and vitality, many specific recommendations, including several imaginative proposals offered by the authors of this book, deserve special attention by policymakers.

60. UNITAR, supra note 1 , at $\mathrm{xv}$. Mr. Jenkins, an authority on international terrorism, is Chairman of the RAND Corporation's Political Science Department and directs their research program on political violence.

61. Jenkins, supra note 9, at 419-420.

62. 1988 Nobel Peace Prize to U.N. Peacekeeping Forces, 25 U.N. CHRON., No. 3, Sept. 1988, at $4-23$.

63. See, e.g., Lewis, Soviets Say U.N. Peace Efforts Should Deal with Prevention, N.Y. Times, Oct. 18, 1988, at A4, col 5 .

64. See, e.g., Big Five Believe in U.N., 25 U.N. Chron., No. 4, Dec. 1988, at 45 . The statements of the Foreign Ministers of five permanent members noted with satisfaction the "marked improvement in international relations at the global level and the general trend towards dialogue and peaceful settlement of disputes" during 1988, and welcomed the United Nations' involvement in the process. Id. 